\title{
The Status of Vitamin D Among Children Aged 0 to 18 Years
}

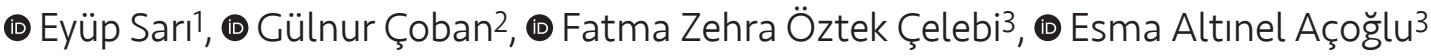

1University of Health Sciences Turkey, Gülhane Faculty of Medicine, Department of Medical Education, Ankara, Turkey

2Provincial Health Directorate, Ankara, Turkey

3University of Health Sciences Turkey, Ankara Dr. Sami Ulus Gynecology, Child Health and Diseases Training and Research Hospital, Clinic of

Pediatrics, Ankara, Turkey

\begin{abstract}
Aim: This study aimed to examine the status of vitamin D in children, to compare vitamin D levels according to the seasons, and to estimate vitamin $D$ testing trends during the years of the study.

Materials and Methods: Blood 25-hydroxyvitamin D [25(OH)D] levels of 51,560 children aged between 0-18 years who had been admitted to nine hospitals between 2015 and 2017 were evaluated. Comparisons of 25(OH)D levels with age groups, gender, and seasons were made. Additionally, vitamin $D$ testing was compared year by year in terms of frequency.

Results: Of the patients, $20 \%(n=10,611)$ had vitamin D deficiency and 34\% $(n=17,385)$ had vitamin D insufficiency. Serum 25(OH)D levels were significantly higher in boys than in girls $(p<0.01)$. There was a significant difference between serum $25(\mathrm{OH}) \mathrm{D}$ levels and the age groups. The highest mean $25(\mathrm{OH}) \mathrm{D}$ levels were detected in infants $(33.95 \mathrm{ng} / \mathrm{mL})$ and the lowest in adolescents $(18.3 \mathrm{ng} / \mathrm{mL})$. Significant seasonal variability of $25(\mathrm{OH}) \mathrm{D}$ levels was detected $(\mathrm{p}<0.01)$. Vitamin $\mathrm{D}$ deficiency was determined most frequently in winter with a frequency of $30.7 \%$. A threefold increase in $25(\mathrm{OH}) \mathrm{D}$ testing was determined over the 3-year period.
\end{abstract}

Conclusion: Female gender, adolescence, and the winter season were found to be important risk factors for vitamin D deficiency or insufficiency. Further evidence is needed to clarify whom to test in order to avoid over-testing.

Keywords: Children, 25-hydroxyvitamin D, seasonality, vitamin D deficiency

\section{Introduction}

The main source (about $90 \%$ ) of vitamin D is synthesized in the skin from provitamin D3 (7-dehydrocholesterol) upon ultraviolet $\mathrm{B}$ exposure and 10\% comes from animalderived foods with oily fish being the most important (1). Vitamin D plays a key role in regulating calcium and phosphorus homeostasis and bone health. Vitamin D also exerts extra-skeletal actions. A growing number of studies have demonstrated that low vitamin $D$ status plays a possible role in the pathogenesis of several pathological conditions, including infectious, allergic, neuropsychiatric, and autoimmune diseases (2).

It is widely acknowledged that 25-hydroxyvitamin D [25(OH)D] serum concentration is the best indicator to evaluate vitamin D status. In the literature, several cutoff points have been proposed for vitamin D levels (2). A global consensus statement of 11 international scientific societies defined 25(OH)D levels as follows; $>50 \mathrm{nmol} / \mathrm{L}$

Address for Correspondence

Esma Altınel Açoğlu, University of Health Sciences Turkey, Ankara Dr. Sami Ulus Gynecology, Child Health and Diseases Training and Research Hospital, Clinic of Pediatrics, Ankara, Turkey 
(>20 ng/mL) indicates sufficiency, 30-50 nmol/L (12-20 $\mathrm{ng} / \mathrm{mL}$ ) indicates insufficiency and $<30 \mathrm{nmol} / \mathrm{L}(<12 \mathrm{ng} /$ $\mathrm{mL}$ ) indicates deficiency (3). Vitamin $D$ insufficiency and deficiency are common worldwide among children of all age groups (4-6).

The winter season, non-white ethnicity, the amount of time spent outdoors during summer, female gender, higher age, higher Tanner stage, and lower household income have all been observed to be associated with vitamin $D$ deficiency in childhood (7). The dietary vitamin D intake is often insufficient to cope with the seasonal deficits of sunlight exposures during winter. Vitamin D deficiency is an important problem in countries with relatively low sun exposure (1). Seasonal variability of $25(\mathrm{OH}) \mathrm{D}$ concentrations in children has been reported in studies from different countries (4-6).

Most patients with vitamin D deficiency are asymptomatic, so whom to test is becoming a major question. Also, increasing awareness of vitamin $D$ deficiency among physicians, the media, and the public causes vitamin $D$ to be more or over investigated in comparison with previous years (8). Reports demonstrate that there is overscreening, overdiagnosis, and overtreatment for vitamin D deficiency in healthy individuals (9). Large increases in vitamin $D$ testing have been reported from Australia, the UK, and the USA in recent years (9-11). A similar increase has been observed in our country, Turkey, but there has been no study on this subject to date. This study aimed to examine vitamin $\mathrm{D}$ status in children aged between 0 and 18 years, to compare vitamin $D$ levels according to the seasons, and to evaluate vitamin $\mathrm{D}$ testing trends during the years of our study.

\section{Materials and Methods}

In this study, the data of 51,560 children aged between 0 and 18 years who had been admitted to nine hospitals in Ankara between the years 2015 and 2017 were evaluated. The hospitals participating in the study were Ankara Dr. Sami Ulus Maternity and Children's Health and Diseases Training and Research Hospital, Ankara Children's HematologyOncology Training and Research Hospital, Ankara Numune Training and Research Hospital, Ankara Yüksek intisas Training and Research Hospital, Dr. Zekai Tahir Burak Women's Health Education and Research Hospital, Ankara Physical Medicine and Rehabilitation Training and Research Hospital, Haymana State Hospital, Şereflikoçhisar State Hospital, and Ankara Gölbaşı Şehit Ahmet Özsoy State Hospital. The present study was approved by the Ethics Committee of Dr. Abdurrahman Yurtaslan Ankara Oncology
Training and Research Hospital (15.05.2019/297). Informed consent was not obtained because this was a retrospective study.

The data regarding blood 25(OH)D levels were obtained from hospital registration systems and recorded on a chart. The children were categorized into age groups as follows; infancy group ( $0-2$ years), preschool age group (3-5 years), school-age group (6-9 years), and adolescents (10-18 years). 25(OH)D level determination had been made by tandem mass spectrometry (LC-MS/MS) using API 3200 (Applied Biosystem Sciex, Concord, Canada, L4K4V8) from blood samples where $25(\mathrm{OH}) \mathrm{D}$ levels were determined in units of " $\mathrm{ng} / \mathrm{mL}$ ". Vitamin $D$ levels were classified into three groups as follows; $<12 \mathrm{ng} / \mathrm{mL}$ indicating deficiency, $12-20$ $\mathrm{ng} / \mathrm{mL}$ indicating insufficiency, and $>20 \mathrm{ng} / \mathrm{mL}$ indicating normal (3). The seasonal variation of serum $25(\mathrm{OH}) \mathrm{D}$ levels was also evaluated. The seasons were categorized as "Spring" (March-April-May), "Summer" (June-July-August), "Autumn" (September-October-November), and "Winter" (December-January-February). Comparisons of 25(OH)D levels with age, gender, and the seasons were made. Vitamin $D$ testing was compared year by year in terms of frequency.

\section{Statistical Analysis}

Statistical analysis of the data was performed using the SPSS 20.0 software system for Windows (IBM Corp., Armonk, NY). Frequency and percentage values were given for nominal variables and mean and standard deviation values for continuous variables. Student's t-test was used to investigate the difference in vitamin $D$ levels between males and females. One-way ANOVA was used to investigate the difference in vitamin $D$ levels according to the seasons and age groups. Differences between each season and age group were compared with Tukey's honestly significant difference test. Nominal variables were compared using Pearson chi-square or Fisher's exact test. $\mathrm{P}<0.05$ was considered statistically significant.

\section{Results}

The mean serum $25(\mathrm{OH}) \mathrm{D}$ level of 51,560 children was $22.86 \pm 16$ (interquartile range: 15$) \mathrm{ng} / \mathrm{mL}$. Of the patients in this study, 28,309 (45\%) were girls and 23,251 (55\%) were boys. The mean serum $25(\mathrm{OH}) \mathrm{D}$ level was $25.1 \pm 16.6 \mathrm{ng} /$ $\mathrm{mL}$ in boys, and $21.0 \pm 15.5 \mathrm{ng} / \mathrm{mL}$ in girls. Serum $25(\mathrm{OH}) \mathrm{D}$ levels were significantly higher in boys than in girls $(p<0.01$, Student's t-test). Of the patients, $20 \%$ ( $n=10,611)$ had vitamin $D$ deficiency and $34 \%(n=17,385)$ had vitamin D insufficiency. It was determined that $61.4 \%(n=37,331)$ of girls and $45.6 \%$ $(n=10,603)$ of boys suffered from vitamin D deficiency or 
insufficiency. Vitamin D deficiency was $26.1 \%(n=7,424)$ in girls and $13.7 \%(n=3,187)$ in boys. Vitamin $D$ insufficiency was $35.2 \%(n=9,969)$ in girls and $31.9 \%(n=7,416)$ in boys $(p<0.01)$. There was a significant difference between serum $25(\mathrm{OH}) \mathrm{D}$ levels in terms of the age groups ( $p<0.01$, ANOVA). The highest mean $25(\mathrm{OH}) \mathrm{D}$ levels were detected in infants $(33.95 \mathrm{ng} / \mathrm{mL})$ and the lowest in adolescents $(18.3 \mathrm{ng} / \mathrm{mL})$ compared with preschool and school-age groups. The mean serum $25(\mathrm{OH}) \mathrm{D}$ levels according to gender and age groups are shown in Table I.

Significant seasonal variability of $25(\mathrm{OH}) \mathrm{D}$ levels was detected ( $p<0.01$, ANOVA). Summer and autumn had higher mean levels of $25(\mathrm{OH}) \mathrm{D}$ than winter and spring. Vitamin $\mathrm{D}$ deficiency was determined most frequently in winter with $30.7 \%$ followed by $28.4 \%$ in spring, $12.7 \%$ in summer, and $12.2 \%$ in autumn. In autumn, the prevalence of vitamin D deficiency $(12.2 \%)$ or insufficiency $(32.6 \%$ ) was $44.8 \%$ in total giving the lowest seasonal percentage. In winter, $64.8 \%$ of children had vitamin D deficiency or insufficiency, and this was the highest percentage among the four seasons. The seasonal variation of $25(\mathrm{OH}) \mathrm{D}$ levels is shown in Table II. The frequency of vitamin $D$ testing was observed to increase gradually. Vitamin D levels were examined in 8,834 children in 2015 and 27,282 in 2017 (Figure 1). A three-fold increase in 25(OH)D testing was determined over a 3-year period.

Multivariate regression analysis showed that being of adolescent age [odds ratio (OR): 6.98], being in the spring season (OR: 2.64) and being a girl (OR: 1.78) were significantly associated with vitamin D insufficiency (95\% confidence interval) (Table III).

\section{Discussion}

Vitamin D deficiency is a serious public health problem worldwide. Vitamin D status has been intensively determined in different populations, including various ethnic and age groups in recent decades (12). In our study, vitamin D deficiency was determined at a frequency of $20 \%$ in our full study population. $26.3 \%$ of girls and $13.8 \%$ of boys had vitamin $D$ deficiency consistent with the literature which reports higher vitamin $D$ deficiency in the female gender (7). In this study, there was a gradual decrease in vitamin $D$ levels with age after infancy. We found vitamin $D$ deficiency at frequencies of $7.9 \%, 12.1 \%, 14.6 \%$, and $29.8 \%$, respectively in infancy, preschool, school, and adolescent age groups. In our study, the mean levels of $25(\mathrm{OH}) \mathrm{D}$

Table I. Vitamin D level classification in children

\begin{tabular}{|c|c|c|c|c|c|c|c|}
\hline \multirow[t]{2}{*}{ Characteristics of children } & \multicolumn{2}{|c|}{$\begin{array}{l}\text { Sufficiency } \\
>20 \mathrm{ng} / \mathrm{mL}\end{array}$} & \multicolumn{2}{|c|}{$\begin{array}{l}\text { Insufficiency } \\
12-20 \mathrm{ng} / \mathrm{mL}\end{array}$} & \multicolumn{2}{|c|}{$\begin{array}{l}\text { Deficiency } \\
<12 \mathrm{ng} / \mathrm{mL}\end{array}$} & \multirow[t]{2}{*}{ p-value } \\
\hline & $\mathbf{n}$ & $\%$ & $\mathbf{n}$ & $\%$ & $\mathbf{n}$ & $\%$ & \\
\hline \multicolumn{7}{|l|}{ Age groups } & \multirow{5}{*}{$<0.01$} \\
\hline Infant ( $0-2$ years) & 7,828 & 75.1 & 1,770 & 17.0 & 824 & 7.9 & \\
\hline Preschool (3-5 years) & 3,478 & 53.4 & 2,235 & 34.4 & 789 & 12.1 & \\
\hline School (6-9 years) & 4,185 & 47.5 & 3,331 & 37.8 & 1,290 & 14.6 & \\
\hline Adolescent (10-18 years) & 8,073 & 31.3 & 10,049 & 38.9 & 7,708 & 29.8 & \\
\hline \multicolumn{7}{|l|}{ Gender } & \multirow{3}{*}{$<0.01$} \\
\hline Boy $(n=23,251)$ & 12,473 & 54.1 & 7,416 & 31.9 & 3,187 & 13.7 & \\
\hline Girl $(n=28,309)$ & 10,754 & 38.2 & 9,969 & 35.2 & 7,424 & 26.2 & \\
\hline
\end{tabular}

Table II. Seasonal variation of serum 25(OH)D levels

\begin{tabular}{|c|c|c|c|c|c|c|c|}
\hline \multirow[t]{2}{*}{ 25(OH)D levels } & \multicolumn{2}{|c|}{$\begin{array}{l}\text { Sufficiency } \\
>20 \mathrm{ng} / \mathrm{mL}\end{array}$} & \multicolumn{2}{|c|}{$\begin{array}{l}\text { Insufficiency } \\
12-20 \mathrm{ng} / \mathrm{mL}\end{array}$} & \multicolumn{2}{|c|}{$\begin{array}{l}\text { Deficiency } \\
<12 \mathrm{ng} / \mathrm{mL}\end{array}$} & \multirow[t]{2}{*}{ p-value } \\
\hline & $\mathbf{n}$ & $\%$ & $\mathbf{n}$ & $\%$ & $\mathbf{n}$ & $\%$ & \\
\hline Spring $(n=12,476)$ & 4,555 & 36.5 & 4,378 & 35.1 & 3,543 & 28.4 & \multirow{5}{*}{$<0.01$} \\
\hline Summer $(n=13,001)$ & 6,998 & 53.8 & 4,355 & 33.5 & 1,648 & 12.7 & \\
\hline Autumn $(n=13,969)$ & 7,715 & 55.2 & 4,554 & 32.6 & 1,700 & 12.2 & \\
\hline Winter $(n=12,114)$ & 4,296 & 35.5 & 4,098 & 33.8 & 3,720 & 30.7 & \\
\hline Total $(n=51,560)$ & 23,598 & 45.7 & 17,385 & 33.7 & 10,611 & 20.6 & \\
\hline
\end{tabular}




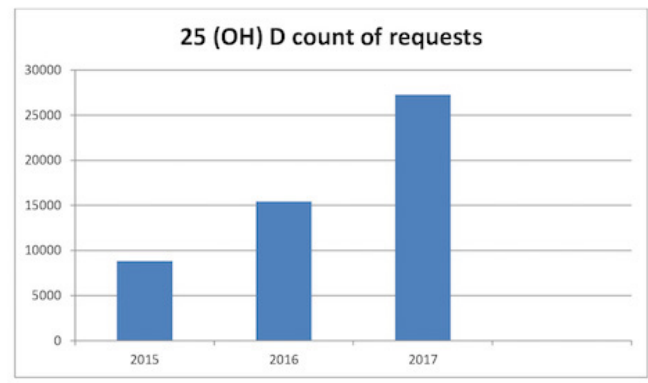

Figure 1. $25(\mathrm{OH}) \mathrm{D}$ count of requests according to years 25(OH)D: 25-hydroxyvitamin D

Table III: The effect of gender, age, and season in determining vitamin D insufficiency

\begin{tabular}{|c|c|c|}
\hline & Adjusted OR $(95 \% \mathrm{Cl})$ & p-value \\
\hline \multicolumn{2}{|l|}{ Gender } & \multirow{3}{*}{$<0.01$} \\
\hline Male (reference) & & \\
\hline Female & $1.78(1.72-1.85)$ & \\
\hline \multicolumn{2}{|l|}{ Age group (years) } & \multirow{5}{*}{$<0.01$} \\
\hline \multicolumn{2}{|l|}{ 0-2 (reference) } & \\
\hline $3-5$ & $2.82(2.63-3.02)$ & \\
\hline $6-9$ & $3.55(3.33-3.78)$ & \\
\hline 10-18 & $6.98(6.61-7.36)$ & \\
\hline \multicolumn{2}{|l|}{ Seasons } & \multirow{5}{*}{$<0.01$} \\
\hline \multicolumn{2}{|l|}{ Autumn (reference) } & \\
\hline Winter & $2.51(2.38-2.64)$ & \\
\hline Spring & $2.64(2.50-2.78)$ & \\
\hline Summer & $1.11(1.05-1.16)$ & \\
\hline
\end{tabular}

were the highest in infants and the lowest in adolescents. Nearly $70 \%$ of adolescents and $25 \%$ of infants were found to have vitamin $D$ deficiency or insufficiency. A daily 400 IU vitamin D supplement is provided to all infants during their first year in Turkey. This supplement may explain why we determined the lowest frequency in the infant group. As age increases, exposure to sunshine decreases due to spending more time indoors in front of a TV or computer. Insufficient playgrounds, the use of sunscreens with high sun protection factors, and covered clothing in adolescent girls have an influence on vitamin D levels $(8,13)$. Vitamin D levels in adolescents may also have been found to be lowest for these reasons in our study. Preschool and school-age children have more chance to spend time outdoors than adolescents in our country because adolescents have to spend more time indoors preparing for exams in order to enter the college or university of their choice among the 2 million individuals they have to compete with.

In the HELENA study, vitamin D levels were determined to be below $30 \mathrm{ng} / \mathrm{mL}$ in approximately $80 \%$ of European adolescents and sufficient 25(OH)D levels were slightly higher in girls than in boys (22\% versus 15\%) (14). Bener et al. (15) reported vitamin D levels below $20 \mathrm{ng} / \mathrm{mL}$ in $61.6 \%$ of adolescents aged 11-16 years, $28.9 \%$ of schoolchildren aged 5-10 years, and $9.5 \%$ of preschool children under the age of 5 years in Qatar, which has ample sunshine. In a study from Afghanistan, vitamin $D$ levels were reported to be $<20 \mathrm{ng} / \mathrm{mL}$ in $61 \%$ of adolescents of whom $65 \%$ were girls. This result was speculated to be related to less sunlight exposure because of the wearing of traditional clothes and inadequate intake of vitamin $\mathrm{D}$ rich foods and supplements (13). The prevalence of 25(OH)D insufficiency among preschool children in Canada was found to be $51.7 \%$ in summer and $72.8 \%$ in winter (6). In another study from Canada, $14 \%$ of children aged 6-11 years had a plasma $25(\mathrm{OH}) \mathrm{D}$ concentration of $<20 \mathrm{ng} / \mathrm{mL}$ (16). Pekkinen et al. (17) determined that $71 \%$ of Finnish children aged 7-11 years had vitamin $D$ levels $<20 \mathrm{ng} / \mathrm{mL}$, despite having met or exceeded the recommended daily intake of vitamin $\mathrm{D}$. Akman et al. (18) reported that vitamin $D$ levels were below $20 \mathrm{ng} / \mathrm{mL}$ in $14.5 \%$ of children aged $1-7$ years.

Vitamin D deficiency has been attracting more attention due to an increase scientific studies and frequent mentions in the media (19). The frequency of testing for vitamin $D$ increased dramatically over an 11-year period in Australia (20). A six-fold increase in 25(OH)D testing was reported between 2007 and 2010 in the UK (8). We determined that there was increased vitamin $D$ testing in Turkey during our study years. This may be because of increased awareness of vitamin D deficiency and its related diseases in recent years. Further evidence is needed to clarify whom to test in order to avoid over-testing and overdiagnosis.

In the literature, vitamin D deficiency has generally been found to be highest in winter or spring $(5,21-23)$. The main factors suggested to be responsible for the seasonal variations of vitamin $D$ are latitude and inadequate sunlight exposure during winter. Between November and February, above a latitude of $37^{\circ}$, there are evident decreases in the number of UVB photons reaching the earth. Furthermore, below a latitude of $37^{\circ}$ and closer to the equator, more vitamin D3 synthesizes in the skin throughout the year (24).

Corrêa et al. (25) reported that vitamin D synthesis may reduce by $39 \%$ in high latitudes in their study regarding effective UV doses for vitamin $D$ synthesis in 
low $\left(10.5^{\circ} \mathrm{N}-16.5^{\circ} \mathrm{S}\right)$, mid $\left(23.6^{\circ} \mathrm{S}-34.6^{\circ} \mathrm{S}\right)$ and high latitudes (54.8 $\left.{ }^{\circ} \mathrm{S}-62.1^{\circ} \mathrm{S}\right)$. In Poland, at $50.3^{\circ} \mathrm{N}-53.4^{\circ} \mathrm{N}$ latitudes at the end of March, a serum concentration of 25(OH)D below 20 $\mathrm{ng} / \mathrm{mL}$ was determined in $84.2 \%$ of children aged between 9 and 13 years (22). Vitamin D deficiency or insufficiency was reported to be $60.2 \%$ in one study involving Norwegian adolescents (Latitude $\left.69^{\circ} \mathrm{N}\right)(26)$. In our study, Vitamin D deficiency $(30.7 \%)$ or insufficiency $(33.8 \%)$ were determined in $64.5 \%$ of the study group in winter in Ankara, which is the capital city of Turkey, at $39^{\circ} \mathrm{N}$ latitude.

\section{Study Limitations}

Our study has some limitations. The data was obtained from both healthy and sick children together and it was gathered retrospectively. Some patients may have diseases which affect vitamin D absorption and metabolism. Moreover, we do not know how much exposure to sunlight children got on a daily basis, their eating habits, their body mass index, or whether or not they took vitamin D supplements. Nevertheless, our study is valuable in being the largest epidemiological study to evaluate vitamin $D$ status in children in Turkey.

\section{Conclusion}

Vitamin D deficiency or insufficiency was determined in more than half of all children in our study. Female gender, adolescence, and also the winter and spring seasons were found to be important risk factors for vitamin D deficiency or insufficiency. The frequency of vitamin D testing has increased dramatically over the years. Further evidence is needed to clarify whom to test. We propose that the Health Ministry pay attention to our study in order to develop a strategy or plan for vitamin $D$ supplementation in adolescents, especially during the winter months.

\section{Ethics}

Ethics Committee Approval: The present study was approved by the Ethics Committee of Dr. Abdurrahman Yurtaslan Ankara Oncology Training and Research Hospital (15.05.2019/297).

Informed Consent: Informed consent was not obtained because this was a retrospective study.

Peer-review: Externally peer-reviewed.

\section{Authorship Contributions}

Concept: E.S., Data Collection or Processing: G.Ç., Analysis or Interpretation: F.Z.Ö.Ç., Literature Search: E.A.A., Writing: E.S., E.A.A.
Conflict of Interest: No conflict of interest was declared by the authors.

Financial Disclosure: The authors declared that this study received no financial support.

\section{References}

1. Wacker M, Holick MF. Vitamin D-effects on skeletal and extraskeletal health and the need for supplementation. Nutrients 2013; 5:111-48.

2. Saggese $G$, Vierucci F, Prodam F, et al. Vitamin D in pediatric age: consensus of the Italian Pediatric Society and the Italian Society of Preventive and Social Pediatrics, jointly with the Italian Federation of Pediatricians. Ital J Pediatr 2018; 44:51.

3. Munns $C F$, Shaw $N$, Kiely $M$, et al. Global consensus recommendations on prevention and management of nutritional rickets. Horm Res Paediatr 2016; 85:83-106.

4. Hilger ), Friedel A, Herr R, et al. A systematic review of vitamin D status in populations worldwide. Br / Nutr 2014; 111:23-45.

5. Smyczynska J, Smyczynska U, Stawerska R, DomagalskaNalewajek $H$, Lewinski A, Hilczer M. Seasonality of vitamin $D$ concentrations and the incidence of vitamin $D$ deficiency in children and adolescents from central Poland. Pediatr Endocrinol Diabetes Metab 2019; 25:54-9.

6. El Hayek J, Pham TT, Finch S, et al. Vitamin D status in Montréal preschoolers is satisfactory despite low vitamin D intake. J Nutr 2013; 143:154-60.

7. Föcker $M$, Antel J, Ring S, et al. Vitamin D and mental health in children and adolescents. Eur Child Adolesc Psychiatry 2017; 26:1043-66.

8. Sattar N, Welsh P, Panarelli M, Forouhi NG. Increasing requests for vitamin $D$ measurement: costly, confusing, and without credibility. Lancet 2012; 379:95-6.

9. Bilinski K, Boyages S. Evidence of overtesting for vitamin D in Australia: an analysis of 4.5 years of Medicare Benefits Schedule (MBS) data. BMJ Open 2013; 3:e002955. doi: 10.1136/ bmjopen-2013-002955.

10. Basatemur E, Hunter R, Horsfall L, Sutcliffe A, Rait G. Costs of vitamin $D$ testing and prescribing among children in primary care. Eur J Pediatr 2017; 176:1405-9.

11. Marcus MB. Vitamin D tests soar as deficiency, diseases linked. USA Today. 2008 Jul 14.

12. Holick MF. The vitamin D deficiency pandemic: Approaches for diagnosis, treatment and prevention. Rev Endocr Metab Disord 2017; 18:153-65.

13. Azizi S, Tariq TM. Vitamin D deficiency among afghan adolescents in Kabul. J Coll Physicians Surg Pak 2019; 29:1072-7.

14. González-Gross M, Valtueña ), Breidenassel C, et al; HELENA Study Group. Vitamin D status among adolescents in Europe: the healthy lifestyle in europe by nutrition in adolescence study. Br J Nutr 2012; 107:755-64.

15. Bener A, Al-Ali M, Hoffmann GF. Vitamin D deficiency in healthy children in a sunny country: associated factors. Int J Food Sci Nutr 2009; 60(Suppl 5):60-70. 
16. Whiting S), Langlois KA, Vatanparast $\mathrm{H}$, Greene-Finestone LS. The vitamin D status of Canadians relative to the 2011 Dietary Reference Intakes: an examination in children and adults with and without supplement use. Am J Clin Nutr 2011; 94:128-35.

17. Pekkinen M, Viljakainen H, Saarnio E, Lamberg-Allardt C, Mäkitie $\mathrm{O}$. Vitamin $\mathrm{D}$ is a major determinant of bone mineral density at school age. PLoS One 2012;7:e40090.

18. Akman AO, Tumer L, Hasanoglu A, Ithan M, Caycı B. Frequency of vitamin $D$ insufficiency in healthy children between 1 and 16 years of age in Turkey. Pediatr Int 2011; 53:968-73.

19. Solak I, Cihan FG, Mercan S, Kethuda T, Eryılmaz MA. Evaluation of 25-Hydroxyvitamin D Levels in Central Anatolia, Turkey. Biomed Res Int 2018; 2018:4076548.

20. Bilinski K, Boyages $\mathrm{S}$. The rise and rise of vitamin D testing. BMJ 2012; 345:e4743.

21. Karagüzel G, Dilber B, Çan G, Ökten A, Değer O, Holick MF. Seasonal vitamin $D$ status of healthy schoolchildren and predictors of low vitamin D status. J Pediatr Gastroenterol Nutr $2014 ; 58: 654-60$.
22. Chlebna-Sokól D, Konstantynowicz J, Abramowicz P, et al. Evidence of a significant vitamin D deficiency among 9-13-yearold Polish children: results of a multicentre study. Eur I Nutr 2019; 58:2029-36.

23. Öhlund I, Silfverdal SA, Hernell O, Lind T. Serum 25-hydroxyvitamin $D$ levels in preschool-age children in northern Sweden are inadequate after summer and diminish further during winter. J Pediatr Gastroenterol Nutr 2013; 56:5515.

24. Holick MF. Sunlight and vitamin D for bone health and prevention of autoimmune diseases, cancers, and cardiovascular disease. Am J Clin Nutr 2004; 80(Suppl 6):1678S-88S

25. Corrêa MP, Yamamoto ALC, Moraes GR, Godin-Beekmann $\mathrm{S}$, Mahé $\mathrm{E}$. Changes in the total ozone content over the period 2006 to 2100 and the effects on the erythemal and vitamin D effective UV doses for South America and Antarctica. Photochem Photobiol Sci 2019; 18:2931-41.

26. Oberg J, Jorde R, Almås B, Emaus N, Grimnes G. Vitamin D deficiency and lifestyle risk factors in a Norwegian adolescent population. Scand J Public Health 2014; 42:593-602. 